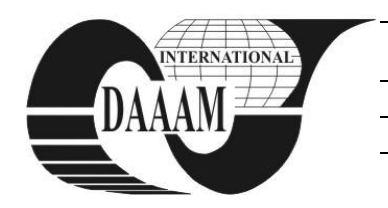

\title{
THE IDENTIFICATION OF VULNERABLE LOCALITIES TO FLASH FLOWS FROM THE INFERIOR BASIN OF JIJIA RIVER THROUGH THE PHYSIOGRAPHIC METHOD
}

\author{
BURUIANA, D[aniel]; APOSTOL, L[iviu]; MACHIDON, O[vidiu] \& BURUIANA, M[ihaela]
}

\begin{abstract}
Climate changes, irrational exploitation of the land and lack of a sustainable protective infrastructure against extreme phenomenological phenomena make Romania an area vulnerable to frequent floods. If on the middle and low courses of major rivers the hydrotechnical infrastructure has been improved in order to prevent against floods, the small water courses often remain vulnerable to flash flooding due to the rains with a torrential character. Such basins quickly respond to heavy precipitations because of the steep slopes and impervious surfaces, saturated soils or because of the anthropogenic changes (deforestation or fires, for example) that cause changes of the natural drainage. Jijia hydrographic basin is an area where the hydrological risk exists and manifests itself along both Jijiariver and its tributaries. The geographical position of the basin and the torrential rains caused by the specific of cyclonal activity in this area create favorable conditions for the release of flash flows in more subbasins. The high amounts of rainfall in a short time produce very large flows which often cannot be taken by minor riverbeds.
\end{abstract}

Keywords:flash floods, Jijia, GIS, hydrological simulation

\section{INTRODUCTION}

Floods represent one of the most disastrous extreme natural phenomena, triggered as a result of direct causal relationship between atmospheric factors (rainfalls) and hydric ones. In many situations, to these are added geomorphic and anthropogenic factors [2].

Floods production is the result of interaction between rainfalls - as generator factor - and the hydrographic basin, which responds in a specific way to the meteorological impulse, according to its hydrological parameters. Extreme hydroclimatic phenomena are risk factors with a large destructive potential. Between the hydrological elements and the climatic ones there is a dependency, extreme hydrological phenomena being triggered and maintained by the climatic ones. As a consequence, floods (the summer ones, specific for the temperate climate areas) are determined primarily by the existence of some rich and torrential rainfalls[3].

The great economic development, the urban and deforested territories expansion induced radical changes in the evolution of hydroclimatic extreme phenomena, the torrential character of rainfalls and water flow being determined by the effect of human activities too.

\section{STUDY AREA}

Jijiariver springs west of Pomârla locality, on the western slope of Bour Massif, Ukraine, which it scrolls through on a distance of $4 \mathrm{~km}$. It is the most important tributary of Prut river, with a length of $275 \mathrm{~km}$, its hydrographic basin area in Romania is $5757 \mathrm{~km}^{2}$.

Jijia hydrographic basin is located in the northeastern part of Romania, on Botoşani and Iaşi counties territories, Fig. 1.

Jijiariver has an average altitude of $152 \mathrm{~m}$, a longitudinal slope of $1 \%$ and a sinuosity coefficient of 1.45 .

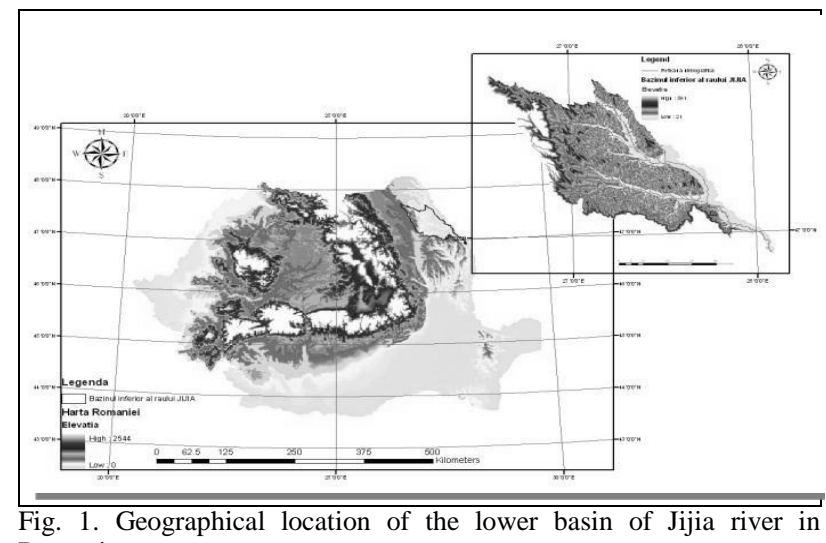
Romania

The river course has been traditionally divided into three sectors (the upper, middle and lower ones) which are distinguished by various specific features, physical and geographical, hydrographical, topographical and hydrological, Fig. 2.

From a mathematical point of view, the $47^{\circ} 36^{\prime} 50^{\prime \prime}$ parallel marks the northernmost point of the lower basin, in Todireni locality (hydrometric station Jijia Todireni) $(80,0 \mathrm{~m})$, and the $47^{\circ} 02^{\prime} 14^{\prime \prime}$ one indicates the southernmost point of the basin, situated in Costuleni locality area (hydrometric station Jijia Chipereşti) (30 m).

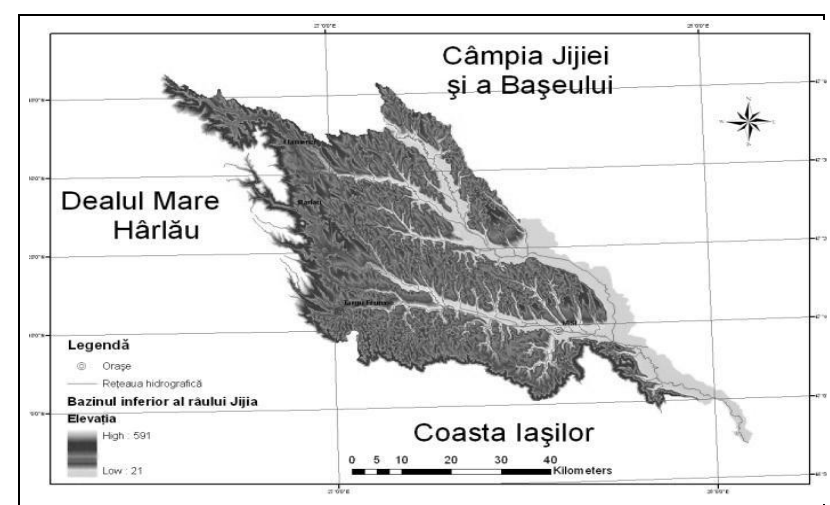

Fig. 2. Lower basin of Jijiariver - relief units map 
The westernmost point is represented by the 2647'48" meridian, in Dealul Mare Hârlău (hydrometric station Vama cu Tablă) $(509,0 \mathrm{~m})$, and the easternmost point is given by the $27^{\circ} 54^{\prime} 46^{\prime \prime}$ meridian, where Jijia river flows into Prut river, at an absolute altitude of $30 \mathrm{~m}$.

\section{RESEARCH METHOD}

A flood caused by torrential rains can be considered a flash one when the following conditions are met (Guide to hydrological practices, World Meteorological Organization, WMO No. 168, 1994):

Water catchment surface is less than 200 square $\mathrm{km}$;

Time of concentration is less than 6 hours;

Duration of torrential rain is 3 hours maximum, usually being less than the basin time of concentration;

The flood is caused by a torrential precipitation that exceeds 1001 per square meter.

Flash floods formation in small basins is conditioned by the processes which take place on the slope and on the torrential formations (paths, ravines, torrents), while flooding production downstream the closing sections of small basins is conditioned not only by the maximum flow generated by a torrential rain, by also by the local transport capacity of the riverbed in localities area.

Preliminary sorting of basins that are likely to generate flash floods, based on the Physiographic Method[1], uses as elements to be processed in GIS[6] digital maps of the lower basin of Jijia, including:Subbasins map (up to the sixth-class ones, with areas of maximum $200 \mathrm{~km}^{2}$, land use map and soil map.By superposition of information in the layers above and basic processing, the digital map of $\mathrm{CN}$ (Curve Number) index of the SCS model is obtained. CN (Curve Number) represents a no dimension index which can range between 0 and 100. $\mathrm{CN}$ depends both on land usage and hydrologic soil group and reflects the water flooding potential on different grounds, as shown in Tab. No. 1 [4]:

\begin{tabular}{|c|c|c|c|c|}
\hline \multirow[t]{2}{*}{ Description of Land Use } & \multicolumn{4}{|c|}{ Hydrologic Soil Group } \\
\hline & $\mathbf{A}$ & B & $\mathbf{C}$ & D \\
\hline Paved parking lots, roofs, driveways & 98 & 98 & 98 & 98 \\
\hline \multicolumn{5}{|l|}{ Streets and Roads: } \\
\hline $\begin{array}{l}\text { Paved with curbs and storm } \\
\text { sewers }\end{array}$ & 98 & 98 & 98 & 98 \\
\hline Gravel & 76 & 85 & 89 & 91 \\
\hline Dirt & 72 & 82 & 87 & 89 \\
\hline \multicolumn{5}{|l|}{ Cultivated (Agricultural Crop) Land*: } \\
\hline $\begin{array}{l}\text { Without conservation treatment } \\
\text { (no terraces) }\end{array}$ & 72 & 81 & 88 & 91 \\
\hline $\begin{array}{l}\text { With conservation treatment } \\
\text { (terraces, contours) }\end{array}$ & 62 & 71 & 78 & 81 \\
\hline \multicolumn{5}{|l|}{ Pasture or Range Land: } \\
\hline $\begin{array}{l}\text { Poor }(<50 \% \text { ground cover or } \\
\text { heavily grazed })\end{array}$ & 68 & 79 & 86 & 89 \\
\hline $\begin{array}{l}\text { Good (50-75\% ground cover; not } \\
\text { heavily grazed) }\end{array}$ & 39 & 61 & 74 & 80 \\
\hline $\begin{array}{l}\text { Meadow (grass, no grazing, mowed } \\
\text { for hay) }\end{array}$ & 30 & 58 & 71 & 78 \\
\hline Brush (good, $>75 \%$ ground cover) & 30 & 48 & 65 & 73 \\
\hline \multicolumn{5}{|l|}{ Woods and Forests: } \\
\hline Poor (small trees/brush destroyed & 45 & 66 & 77 & 83 \\
\hline
\end{tabular}

\begin{tabular}{|c|c|c|c|c|}
\hline by over-grazing or burning) & & & & \\
\hline $\begin{array}{l}\text { Fair (grazing but not burned; } \\
\text { some brush) }\end{array}$ & 36 & 60 & 73 & 79 \\
\hline $\begin{array}{l}\text { Good (no grazing; brush covers } \\
\text { ground) }\end{array}$ & 30 & 55 & 70 & 77 \\
\hline \multicolumn{5}{|c|}{ Open Spaces (lawns, parks, golf courses, cemeteries, etc.): } \\
\hline $\begin{array}{l}\text { Fair (grass covers } 50-75 \% \text { of } \\
\text { area) }\end{array}$ & 49 & 69 & 79 & 84 \\
\hline Good (grass covers $>75 \%$ of area) & 39 & 61 & 74 & 80 \\
\hline $\begin{array}{l}\text { Commercial and Business Districts } \\
\text { (85\% impervious) }\end{array}$ & 89 & 92 & 94 & 95 \\
\hline Industrial Districts (72\% impervious) & 81 & 88 & 91 & 93 \\
\hline \multicolumn{5}{|l|}{ Residential Areas: } \\
\hline $\begin{array}{l}1 / 8 \text { Acre lots, about } 65 \% \\
\text { impervious }\end{array}$ & 77 & 85 & 90 & 92 \\
\hline $\begin{array}{l}1 / 4 \text { Acre lots, about } 38 \% \\
\text { impervious }\end{array}$ & 61 & 75 & 83 & 87 \\
\hline $\begin{array}{l}1 / 2 \text { Acre lots, about } 25 \% \\
\text { impervious }\end{array}$ & 54 & 70 & 80 & 85 \\
\hline $\begin{array}{l}1 \text { Acre lots, about } 20 \% \\
\text { impervious }\end{array}$ & 51 & 68 & 79 & 84 \\
\hline
\end{tabular}

Tab. No. 1: CN coefficient values

For a given basin, $\mathrm{CN}$ global index is obtained as a weighted average with partial surfaces $F_{i}$, characterized by $\mathrm{CN}_{\mathrm{i}}$ index. Based on this map, concentration time will be calculated, according to the diagram in Fig. 3 .

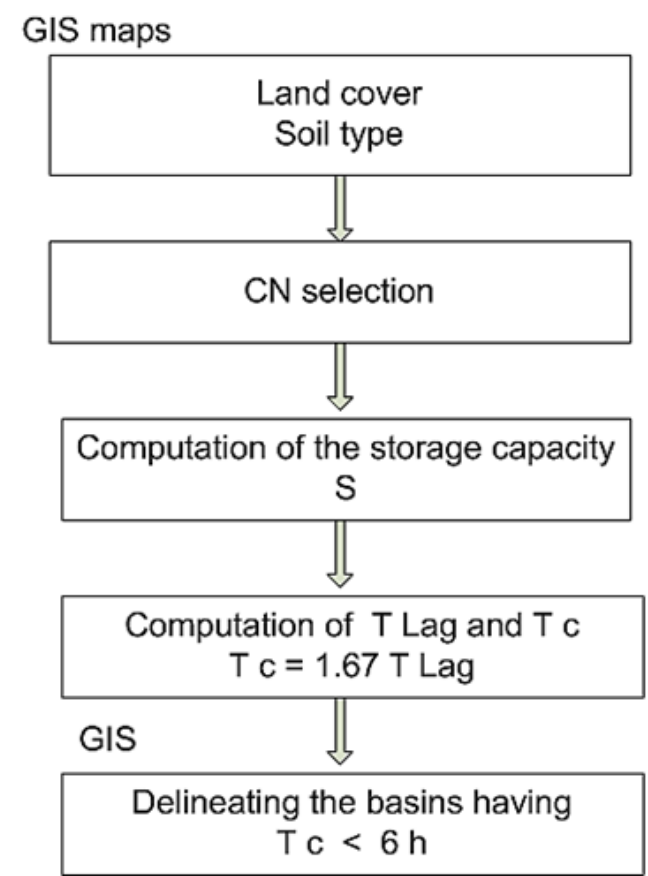

Fig. 3. Physiographic method steps

Parameters that appear in this Fig. are as below:

$\mathrm{T}_{\mathrm{C}}$ - concentration time (hours) - period of time required for storm runoff to flow to the outlet from the point of a drainage basin having the longest travel time.

$$
T_{L A G}=(3,28084 * L)^{0,8} * \frac{(S+1)^{0,7}}{1900 \sqrt{I_{B}}}
$$

where: $\mathrm{T}_{\mathrm{LAG}}-$ lag time (hours) is the period of time between the peak of a storm event and the flood peak

$\mathrm{L}$ - length of main river bed (m);

$\mathrm{I}_{\mathrm{B}}$ - average slope of the basin \%;

[5] maximum storage capacity 


$$
S=\frac{1000}{C N}-10
$$

Both $\mathrm{L}$ and $\mathrm{I}_{\mathrm{B}}$ are obtained based on processing GIS maps using an appropriate scale. As a result of this procedure, the identification of basins having Tc $<6$ hours is obtained. As recommended in literature a time of concentration smaller as 6 hours represents a significant hydrologic risk to flash floods. By the superposition in GIS with human settlements map in the lower basin of Jijia, the localities vulnerable to flash flooding can be identified.

\section{CASE STUDY}

According to the previous chapter, it is necessary to superposition the following data, in GIS format:

Sub-basins map: This layer uses polygonal data in vector format. In Romanian Waters Cadastre, published in 1992, there are 89 sub-basins in the lower basin of Jijia, up to the sixth-class ones, with areas ranging between $8 \mathrm{~km}^{2}$ and $117 \mathrm{~km}^{2}$. The attributes associated with this layer are river lengths, average slope, average altitude, surface etc.,Fig. 4.

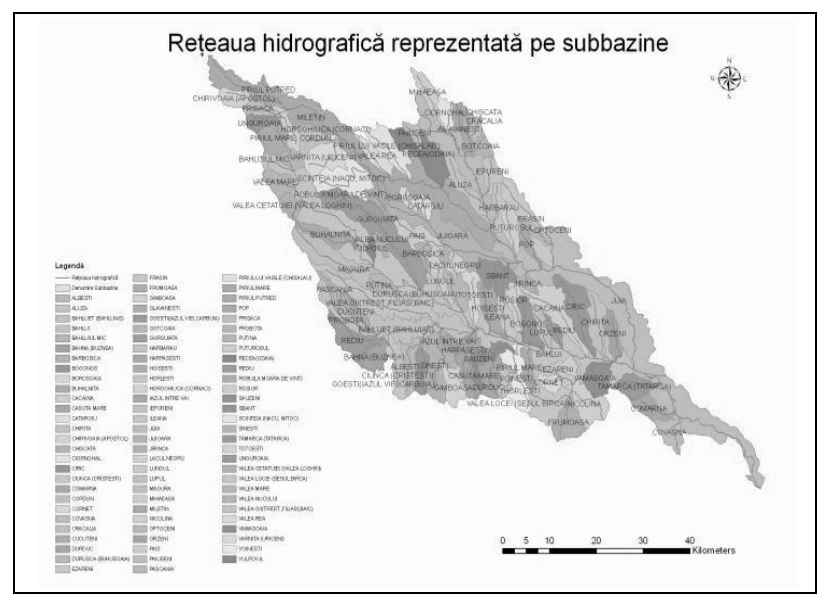

Fig. 4. Watersheds

Land use map: in order to determine the specific values for Romania, the thematic layer "Corine Land Cover 2000", realized by NIRD "Delta Dunarii" Tulcea, has been used, Fig. 5 .

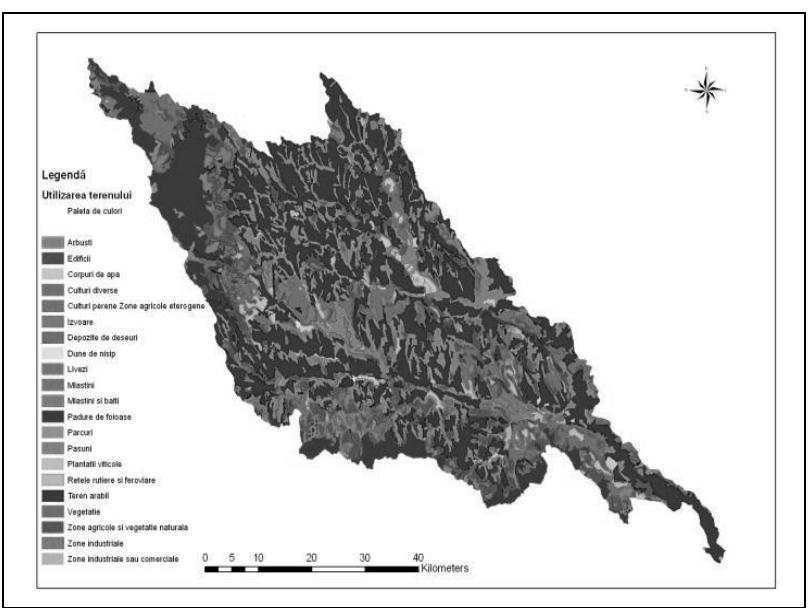

Fig. 5. Land use map
Soil map: this layer contains soil structure and the main soil groups, highlighting their outflow potential, Fig. 6.

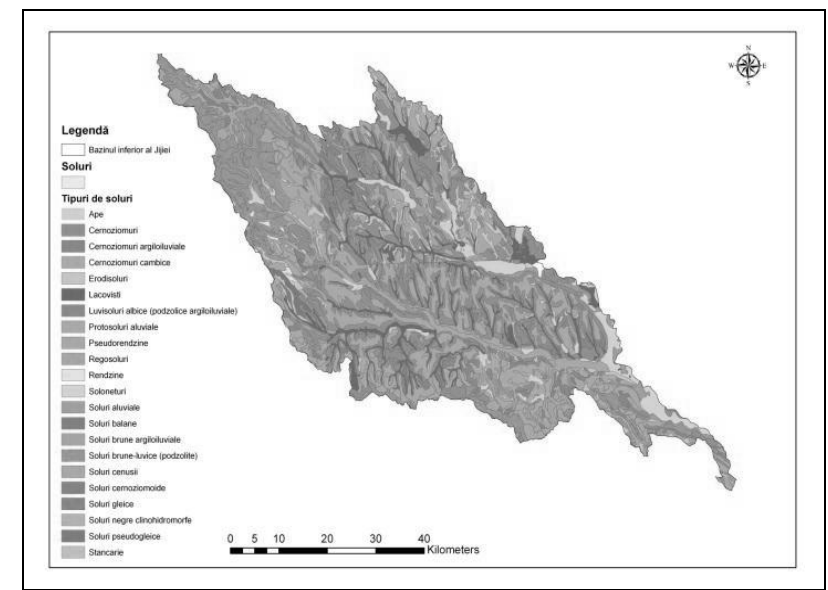

Fig. 6. Soil map

All basins with a concentration time value less than or equal to 6 hours are considered to be vulnerable to flash floods, Fig. 7.

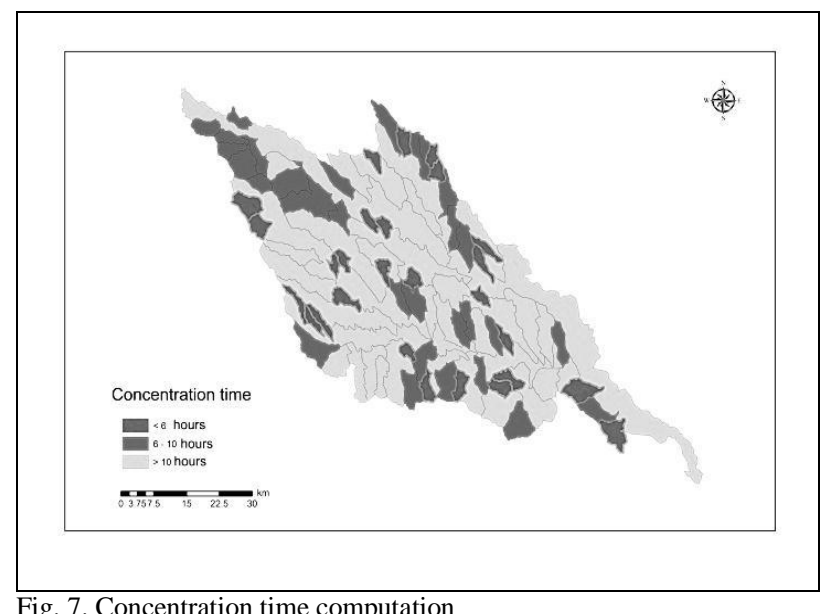

Overlapped mostly over Iaşi county, the lower hydrographic basin of Jijia contains 301 localities (including Iaşi municipality and Târgu-Frumos, Hârlău, Podu Iloaiei cities) with a population exceeding 750000 inhabitants, Fig. 8.

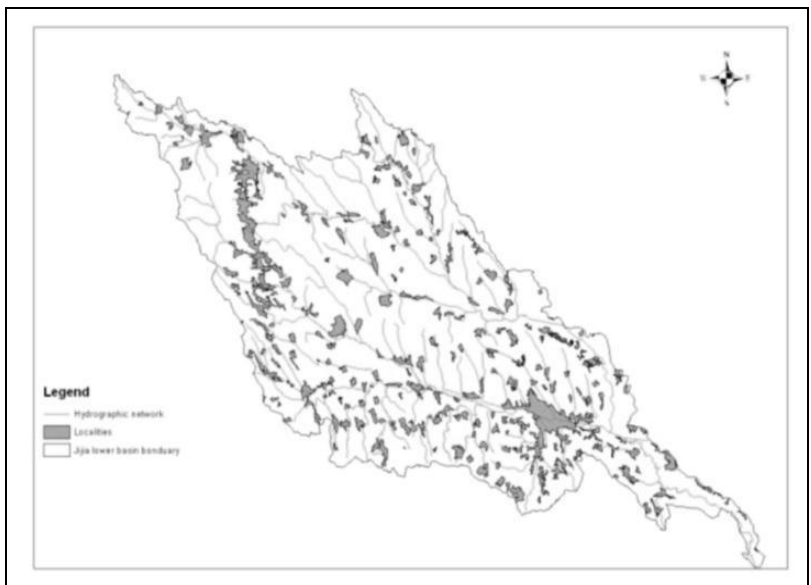

Fig. 8. Human settlements map on lower hydrographic basin of Jijia 
By superimposing the layer containing human settlements over the layer containing the spatial distribution of sub-basins that have a CT (concentration time) of less than 6 hours, it will be revealed a new layer that will indicate those localities from the lower basin of Jijia that are vulnerable to flash floods, Fig. 9.

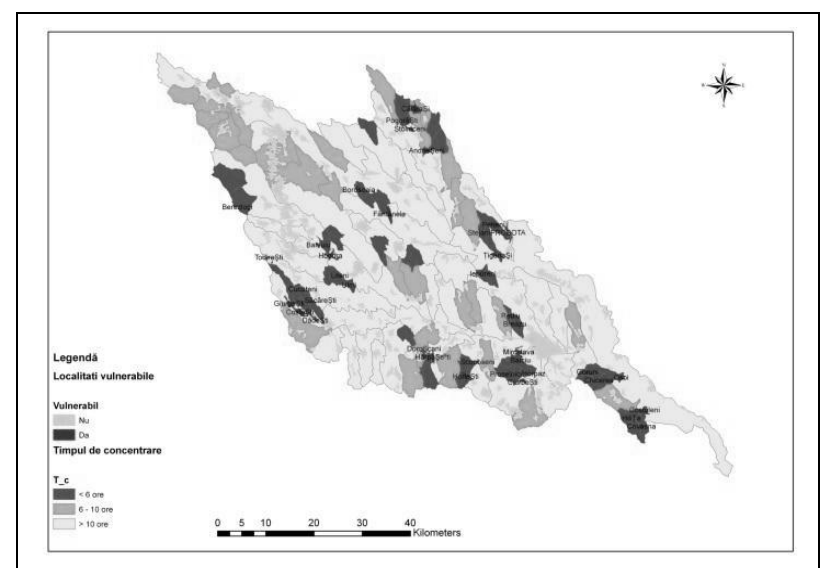

Fig. 9. The map of human settlements that are vulnerable to flash floods from the lower hydrographic basin of Jijia

\section{REASEARCH RESULTS. DISCUSSION}

Following the sorting of basins that are likely to generate flash floods, based on physiographic method, there have been identified 28 sub-basins of different classes that are vulnerable to the production of flash floods. Most of these basins are in the western and southwestern part of the lower basin of Jijia, where the basin slope allows a water concentration at the minor bed level;

After overlapping the layer that contains human settlements with the layer that contains the spatial distribution of concentration time, there have been identified 44 localities located in sub-basins, that are vulnerable to the production of flash floods;

This study represents a preliminary evaluation of vulnerability to flash floods in the lower basin of Jijia, study that indicates us the localities that may be directly affected by rains with a torrential character. Further to this work, it can be developed a GIS methodology in order to model the rainfall-water leak process to help the anticipation of water amount available for leakage and integration of the leakage on the slopes in order to estimate the magnitude of flash floods that can occur. Thus, it is aimed, in terms of a forecast of a quantity of precipitations for a day, the previous conditions of humidity and soil characteristics being known, to estimate the water quantity which will contribute to flood generation and distribution of the leakage of this quantity of water in space and time.

\section{CONCLUSIONS}

Jijia hydrographic basin is an area where the hydrological risk exists and manifests itself both along Jijiariver and its tributaries. The geographical position of the basin and the torrential rains determined by the specific of cyclonal activity in this area create favorable conditions for flash floods triggering in 28 sub-basins. The high quantities of precipitations in a short time produce very large flow rates, debits that often cannot be taken by the river beds.

As for the 44 localities directly exposed, maintaining the transit capacity of the river bed has a paramount role in floods prevention.

Based on correlations, thresholds of the characteristics of precipitations that can trigger flash floods (amount, duration etc.) can be predetermined. When forecasting or recording these predetermined values in operative, warnings can be issued for the decision factors, which can estimate the gravity and risk of the event.

Climate change, chaotic development, without taking into account floodable areas, but also the increased erosion lead to an increased economic and social vulnerability regarding the flooding risk.

\section{ACKNOWLEDGMENTS}

O. Machidon is supported by a POSDRU grant no. 89/1.5/S/49944 "Developing the innovation capacity and improving the impact of research through post-doctoral programs", AlexandruIoanCuza University, Iasi.

\section{REFERENCES}

[1] Drobot R., Metodologia de determinare a bazinelor hidrografice torentiale in care se afla asezari umane expuse pericolului viiturilor rapide. UTCB Bucuresti, 2007

[2] Bălteanu D., Alexe Rădiţa, Hazarde naturale şi antropice, Editura Corint, Bucharest, (2001)

[3] D. Buruiană, L. Apostol, D. Machidon, M. Buruiană,Some Aspects of Hydrological Risk Manifestation in JijiaBasin,Air and water components of the environment, ISSN:2067-743X, ClujNapoca, (2012)

[4] VenTe Chow, David R. Maidment, Larry W. Mays, Applied Hydrology - Civil Engineering, Editura: Mcgraw-Hill Education - Europe,Colectia: Civil Engineering, 1988

[5] **** Iowa Stormwater Management Manual, 2C-3 Time of Concentration. Version 2; December 5, 2008

[6] **** ESRI U.S.A., ArcGIS 9 Getting Started With ArcGIS, 2004 